\title{
Studi Time Series Dinamika Lingkungan Terhadap Kejadian DBD Berbasis Geographic Information System
}

\author{
Arifatun Nisaa \\ Prodi. Perekam dan Informasi Kesehatan, FKM, Universitas Veteran Bangun Nusantara \\ Email: arifatun.nisaa@gmail.com
}

\begin{abstract}
GIS becomes one of the fastest growing disciplines in the midst of rapidly mapping technology, especially in health related to the distribution of disease, such as distribution of dengue cases. This study uses study time series, 2010-2014. Data used are data of DHF distribution and land use data from BPS, BMKG and BPS. While in this study besides using GPS also utilize ArcGIS 10.1 software. Dengue fever spreads in residential areas. And climatological conditions (temperature and rainfall) support the breeding of Aedes Aegypty mosquitoes. However, the variables studied can not be tested correlation because in this study only descriptive research. This research can be developed by the next researcher, with analytical method to test the correlation between research variables and the development of early awareness system of DHF outbreak.
\end{abstract}

Keywords: DHF, Dynamics environment, multi temporal analysis, spatial, GIS

\begin{abstract}
ABSTRAK
SIG menjadi satu disiplin ilmu yang berkembang pesat saat ini ditengah pesatnya teknologi pemetaan khususnya bidang kesehatan terkait dengan sebaran suatu penyakit, seperti sebaran kasus DBD. Penelitian ini menggunakan study time series, tahun 2010-2014. Data yang digunakan adalah data sebaran DBD dan data penggunaan lahan dari BPS, BMKG dan BPS. Sedangkan pada penelitian ini selain menggunakan GPS juga memanfaatkan software ArcGIS 10.1. Sebaran kasus DBD mengelompok di wilayah pemukiman. Dan kondisi klimatologi (suhu dan curah hujan) mendukung perkembangbiakan nyamuk Aedes Aegypty. Namun, variabel yang diteliti tidak dapat diuji korelasinya karena dalam penelitian ini hanya penelitian deskriptif. Penelitian ini bisa dikembangkan oleh peneliti selanjutnya, dengan metode analitik untuk menguji korelasi antar variabel penelitian serta pengembangan sistem kewaspadaan dini KLB DBD.
\end{abstract}

Kata kunci: DBD, Dinamika lingkungan, multi temporal analisis, spasial, SIG 


\section{PENDAHULUAN}

Penyebaran populasi Aedes aegypti erat kaitannya dengan perkembangan permukiman penduduk akibat didirikannya rumah-rumah baru yang dilengkapi sarana pengadaan dan penyimpanan air untuk keperluan sehari-hari. Terdapat keterkaitan antara pola/tata letak permukiman dengan perkembangan nyamuk Aedes aegypti, asumsinya bahwa pada daerah yang permukimannya padat dan tidak teratur menyebabkan kendala seperti saluran pembuangan limbah dan saluran air hujan yang tidak memadai, banyak rumah yang asal membangun sehingga tidak terdapat cukup cahaya masuk. Hal ini mengakibatkan kelembaban udara tinggi yang mempermudah perkembangbiakan nyamuk Aedes aegypti.

Faktor curah hujan mempunyai hubungan erat dengan laju peningkatan populasi Aedes aegypti. Pada musim kemarau banyak barang bekas seperti kaleng, gelas plastik, ban bekas, dan sejenisnya yang dibuang atau ditaruh tidak teratur di sembarang tempat. Sasaran pembuangan atau penaruhan barang-barang bekas tersebut biasanya tempat terbuka, seperti lahan-lahan kosong atau lahan tidur yang ada di daerah perkotaan maupun di daerah perdesaan. Ketika cuaca berubah dari musim kemarau ke musim hujan sebagian besar permukaan tanah dan barang bekas itu menjadi sarana penampung air hujan. Bila di antara tempat atau barang bekas itu berisi telur hibernasi maka dalam waktu singkat akan menetas menjadi larva Aedes aegypti yang dalam waktu (9-12 hari) menjadi imago. Fenomena lahan kosong sering menjadi tempat pembuangan sampah rumah tangga termasuk barang kaleng yang potensial sebagai tempat pembiakan nyamuk (Tavares, A.O., Mario Monteiro., M.A. Vargas., 2014). Curah hujan dapat menambah jumlah tempat perkembangbiakan vektor (breeding places) atau dapat pula menghilangkan tempat perindukan. Curah hujan dapat juga berpengaruh terhadap suhu dan kelembaban nisbi udara. Menurut Cahyati (2006) bahwa curah hujan $140 \mathrm{~mm} / \mathrm{minggu}$ dapat menghambat berkembangbiaknya nyamuk. Curah hujan yang lebat menyebabkan bersihnya tempat perindukan vektor oleh karena hanyut terbawa aliran air yang menyebabkan matinya larva/jentik nyamuk.

Suhu mempengaruhi menetasnya larva Aedes aegypti menjadi pupa dan dewasa. Suhu yang terbaik menetaskan larva menjadi dewasa antara suhu $26{ }^{\circ} \mathrm{C}-32{ }^{\circ} \mathrm{C}$, bila suhu terlalu ekstrim dibawah $26^{\circ} \mathrm{C}$ atau di atas $32{ }^{\circ} \mathrm{C}$ maka daya penetasan larva menjadi dewasa akan menurun (Cahyati, 2006). Walaupun pada suhu $10{ }^{\circ} \mathrm{C}$ larva. Aedes aegypti akan menetas tapi tidak begitu sempurna. Faktor suhu akan dipengaruhi oleh curah hujan pada suatu daerah, sehingga faktor iklim (curah hujan, suhu dan kelembaban udara) menjadi penting dalam penentuan pengendalian DBD (Brunkard et al., 2007). Berbagai faktor iklim terhadap DBD, dimana nyamuk dapat bertahan hidup pada suhu rendah tetapi metabolismenya menurun atau bahkan terhenti bila suhu udara turun sampai di bawah suhu kritis. Pada suhu yang lebih tinggi dari $32{ }^{\circ} \mathrm{C}$ juga dapat mempengaruhi proses fisiologis, rata-rata suhu optimum untuk pertumbuhan nyamuk adalah $26^{\circ} \mathrm{C}-32 \circ \mathrm{C}$. Pertumbuhan nyamuk akan terhenti sama sekali bila suhu kurang dari $10^{\circ} \mathrm{C}$ atau lebih dari $40^{\circ} \mathrm{C}$, sedangkan untuk pertumbuhan jentik diperlukan suhu udara berkisar $26^{\circ} \mathrm{C}$ $32{ }^{\circ}$ C. Kelembaban udara merupakan faktor penting dalam pertumbuhan nyamuk. Kelembaban optimal yang diperlukan untuk pertumbuhan nyamuk berkisar antara $60-80 \%$. Umur nyamuk Aedes aegypti betina rata-rata mencapai 10 hari. Namun, dengan keadaan suhu udara dan kelembaban yang optimal umur nyamuk dapat mencapai lebih dari 1 (satu) bulan. Secara tidak langsung kelembaban dapat berpengaruh terhadap umur nyamuk dalam kesempatannya untuk menjadi vektor. Pada kelembaban yang tinggi menyebabkan nyamuk cepat lemah dan dapat menyebabkan kematian. Pada kelembaban kurang dari 60\% umur nyamuk akan menjadi pendek sehingga tidak cukup untuk siklus pertumbuhan virus dalam tubuh nyamuk (Bouzid et al., 2014).

Sistem Informasi Geografi (SIG) dalam era pembangunan dewasa ini sangatlah bermanfaat. Informas-informasi tentang bentang alam dan bentang budaya sangatlah diperlukan dalam proses pembangunan demi kemajuan suatu bangsa. Dalam bidang kesehatan SIG berguna untuk penyediaan data atribut dan data spasial yang menggambarkan distribusi atau pola spasial penyebaran penyakit, dan lain-lain.

Kabupaten X merupakan wilayah yang endemis DBD. Faktanya, dalam 3 tahun terakhir memiliki jumlah kejadian DBD tertinggi dibandingkan dengan wilayah lainnya. Penelitian terkait unsur klimatologi dan 
penggunaan lahan dengan DBD sudah banyak dilakukan. Namun, di Kabupaten ini belum pernah dilakukan dan ini penting sebagai upaya kewaspadaan dini kemungkinan adanya KLB DBD. Oleh karena itu, dilakukan Studi Time Series Dinamika Lingkungan Terhadap Kejadian DBD Di Kab X Berbasis Geographic Information System

\section{METODE}

Penelitian dilaksanakan di Kabupaten X, dan merupakan penelitian deskriptif dengan cara multi temporal analysis menggunakan data kejadian DBD, data penggunaan lahan dan data klimatologi (suhu, kelembaban, curah hujan, kecepatan angin). Peta Rupa Bumi dari Bakosurtanal dengan skala 1:25.000. Data penggunaan lahan dan peta administrasi dalam format shapefile (shp) dari Bappeda. Data klimatologi dari Stasiun Pengamatan di Bagian Komando Pendidikan Angkatan Udara Pangkalan TNI AU dan BMKG. Pencatatan titik koordinat posisi rumah penderita DBD menggunakan lembar pencatatan dan GPS Alat yang digunakan antara lain: Laptop dengan Random Access Memory (RAM) 4 GB HD 500GB, Prosesor Intel(R) Core(TM) i54200U, Global Positioning System (GPS), untuk menentukan titik sampel penderita kasus DBD di lapangan. Software Arc GIS 10.0 untuk membuat penyajian peta lengkap dengan judul peta, legenda, skala dan sumber peta. untuk mendeskripsikan faktor klimatologi (suhu, curah hujan dan penggunaan lahan), dan distribusi kejadian DBD tahun 2010-2014, yang disajikan dalam bentuk tabel distribusi frekuensi maupun grafik, sehingga akan tergambar fenomena yang berhubungan dengan variabel yang diteliti.

\section{HASIL}

\section{Gambaran Sebaran DBD di Kabupaten} $\mathbf{X}$

Tabel 1. Distribusi Kejadian DBD di Kabupaten X Tahun 2010-2014

\begin{tabular}{cccc}
\hline Tahun & $\begin{array}{c}\text { Rata- } \\
\text { rata }\end{array}$ & $\begin{array}{c}\text { Standar } \\
\text { Deviasi }\end{array}$ & $\begin{array}{c}\text { Min- } \\
\text { Maks }\end{array}$ \\
\hline 2010 & 12,58 & 9,07 & $1-34$ \\
\hline 2011 & 2,58 & 2,64 & $0-10$ \\
\hline 2012 & 2,83 & 2,65 & $1-9$ \\
\hline 2013 & 13,92 & 9,75 & $2-30$ \\
\hline
\end{tabular}

\begin{tabular}{cccc}
\hline 2014 & 7,75 & 3,62 & $2-15$ \\
\hline $\mathbf{2 0 1 0 -}$ & $\mathbf{7 , 9 3}$ & $\mathbf{7 , 8 1}$ & $\mathbf{0 - 3 4}$ \\
$\mathbf{2 0 1 4}$ & & & \\
\hline
\end{tabular}

Hasil analisis data kejadian DBD tahun 20102014 diperoleh rata-rata kejadian sebanyak 8 kejadian dengan standar deviasi 7,81. Jumlah kejadian terendah yaitu 0 kejadian dan kejadian tertinggi 34 kejadian. Dalam kurun waktu 2010-2014, kejadian DBD tertinggi terjadi pada bulan april (14 kasus), mei (12 kasus) dan juni (16 kasus). Kondisi curah hujan sangat lebat, suhu udara sedang dan kelembaban tinggi cenderung terjadi pada bulan januari dan februari meskipun kejadian DBD saat itu tergolong rendah. Pada bulan januari tahun 2010-2014 ketika rata-rata curah hujan sangat lebat $(481,98 \mathrm{~mm})$, suhu udara $26,48{ }^{\circ} \mathrm{C}$, kelembaban tinggi (84,32\%), dan kecepatan angin $5,2 \mathrm{~km} / \mathrm{jam}$, kejadian DBD yang terjadi hanya sejumlah 7 kasus. Justru pada kondisi suhu $27,83^{\circ} \mathrm{C}$ dengan kelembaban $78,96 \%$ dan curah hujan $373,58 \mathrm{~mm}$, serta kecepatan angin $6,2 \mathrm{~km} / \mathrm{jam}$ kejadian DBD yang terjadi sejumlah 14 kasus. Kondisi tersebut terulang pada bulan juni ketika suhu yang tinggi $27,76^{\circ} \mathrm{C}$, kelembaban berkisar $74,42 \%$, kecepatan angin $5,8 \mathrm{~km} / \mathrm{jam}$, jumlah kejadian DBD sejumlah 16 kasus.

\section{Gambaran Lingkungan Fisik}

\section{a. Suhu}

Suhu rata-rata terendah terjadi pada tahun 2011, yaitu $27,5^{\circ} \mathrm{C}$ dan suhu tertinggi terjadi pada tahun 2014, yaitu $27,87{ }^{\circ} \mathrm{C}$. Suhu minimum yang terjadi pada tahun 2011 adalah $26,4{ }^{\circ} \mathrm{C}$ sedangkan suhu maksimumnya $30,1{ }^{\circ} \mathrm{C}$. Pada tahun 2014 suhu minimumnya $26,3^{\circ} \mathrm{C}$ dan suhu maksimumnya adalah $30{ }^{\circ} \mathrm{C}$.

Tabel 2. Distribusi Suhu di Kabupaten X

\begin{tabular}{cccc}
\hline Tahun & Rata-rata & $\begin{array}{c}\text { Standar } \\
\text { Deviasi }\end{array}$ & $\begin{array}{c}\text { Min- } \\
\text { Maks }\end{array}$ \\
\hline 2010 & 27,71 & 0,58 & $26,5-28,4$ \\
\hline 2011 & 27,54 & 1,03 & $26,4-30,1$ \\
\hline 2012 & 27,74 & 0,78 & $26,6-29,2$ \\
\hline 2013 & 27,64 & 0,68 & $26,6-29,3$ \\
\hline 2014 & 27,87 & 1,03 & $26,3-30$ \\
\hline $\mathbf{2 0 1 0 - 2 0 1 4}$ & $\mathbf{2 7 , 7 0}$ & $\mathbf{0 , 8 2 0}$ & $\mathbf{2 6 . 3 - 3 0 , 1}$ \\
\hline
\end{tabular}

Hasil analisis data suhu udara diperoleh ratarata suhu udara tahun 2010-2014 adalah $27,70^{\circ} \mathrm{C}$, suhu minimum $26,3{ }^{\circ} \mathrm{C}$ dan suhu maksimum $30,1^{\circ} \mathrm{C}$.

\section{b. Curah Hujan}

Curah hujan pada bulan agustus tahun 2012 mengalami peningkatan yang signifikan yaitu $655,8 \mathrm{~mm}$ dibandingkan pada bulan 
sebelumnya yang hanya $0,2 \mathrm{~mm}$. Pada bulan September tahun 2011-2014 tidak terjadi hujan. Curah hujan rata-rata terendah terjadi pada tahun 2014 yaitu 141,92 mm. Sedangkan ratarata curah hujan tertinggi terjadi pada tahun 2012 yaitu 321,67mm. Gambaran curah hujan di Kabupaten X pada periode waktu 2010-2014 ditunjukkan pada grafik berikut.

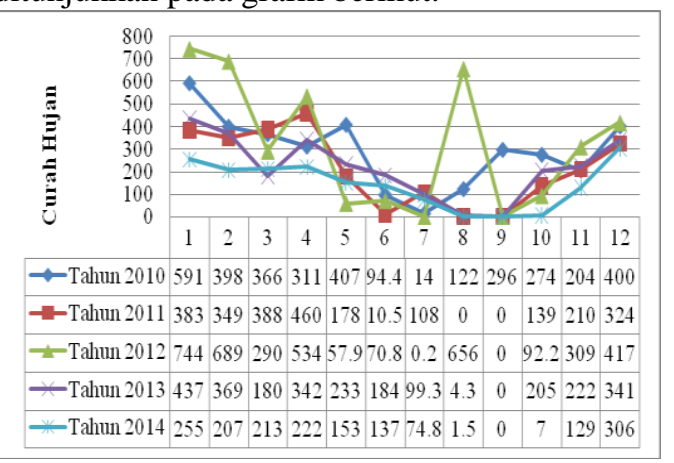

Gambar 1. Grafik Curah Hujan di Kabupaten X

$$
\text { c. Penggunaan Lahan }
$$

Penggunaan lahan berdasarkan data BPS Kabupaten Karanganyar (2014)(BPS Kabupaten Karanganyar, 2014), pada tahun 2013 terjadi perubahan penggunaan lahan pada tanah sawah dari 520 Ha menjadi 484,6 Ha dan tanah kering dari $964 \mathrm{Ha}$ menjadi 999,4 Ha. Sedangkan pada tahun 2014 penggunaan lahan pada tanah sawah berubah dari 484,6 $\mathrm{Ha}$ menjadi 509 Ha dan penggunaan tanah kering dari 999,4 Ha menjadi 1055,17 (BPS, 2015).

\section{PEMBAHASAN}

\section{Gambaran Sebaran DBD}

Penularan penyakit DBD dipengaruhi oleh interaksi yang kompleks antara vektor, host dan virus. Penggunaan lahan seperti bendungan air atau praktek pertanian tertentu telah diidentifikasi sebagai faktor risiko demam berdarah karena penyediaan habitat yang cocok untuk vektor. Banyak penelitian telah difokuskan pada faktor penggunaan lahan dan tingginya jumlah vektor dengue di daerah kecil tapi belum mempelajari hubungan antara faktor-faktor penggunaan lahan dan kasus demam berdarah dengue untuk daerah besar. Penelitian Cheong et al., (2014) bertujuan untuk menjelaskan jika penggunaan lahan selain faktor pemukiman manusia, misalnya berbagai jenis penggunaan lahan pertanian, bendungan air dan hutan juga terkait dengan kasus demam berdarah dengue dilaporkan 2008-2010 di negara bagian Selangor,
Malaysia. Dari study korelatif menghasilkan peta resiko prediksi. Hasil menunjukkan bahwa faktor penggunaan lahan yang paling berpengaruh adalah pemukiman manusia $(39,2 \%)$, diikuti oleh badan air $(16,1 \%)$, hortikultura campuran $(8,7 \%)$, lahan terbuka $(7,5 \%)$ dan padang rumput $(6,7 \%)$ (Cheong, Leitao dan Lakes, 2014).

Sebagai upaya kewaspadaan dini terhadap kemungkinan adanya KLB DBD dalam tahuntahun berikutnya, sebaiknya dilakukan pencegahan dengan cara melepaskan nyamuk Aedes aegypti yang mengandung bakteri Wolbachia. Seperti diketahui, wolbachia adalah bakteri alami yang terdapat pada sel tubuh serangga dan ditemukan di 60 persen spesies serangga seperti rengat, lalat buah, capung, kumbang, hingga nyamuk. Namun bakteri ini tidak ada pada nyamuk Aedes aegypti yang selama ini dikenal sebagai vektor penular virus dengue. Dengan menyuntikkan bakteri wolbachia ke tubuh nyamuk, dan menyebarkan nyamuk tersebut ke daerah yang sering ditemukan kasus DBD. Harapannya dengan penyebaran nyamuk wolbachia ini, nyamuk penular virus dengue akan berkurang. Di sejumlah kecamatan seperti yang telah diterapkan oleh Eliminate Dengue Project (EDP) sejak 2014 lalu. Penelitian laboratorium menunjukkan keberadaan bakteri ini mampu menghambat pertumbuhan virus dengue dalam tubuh nyamuk. Dengan demikian, dapat mengurangi secara signifikan nyamuk yang dapat menyebabkan DBD. Metode ini sudah diteliti dengan melepaskan ribuan nyamuk berwolbachia di dua padukuhan, Kronggahan dan Nogotirto, Sleman. Setelah adanya pelepasan ribuan nyamuk berbakteri wolbachia, di padukuhan Kronggahan dan Nogotirto tidak ditemukan masyarakat yang terkena DBD.

\section{Gambaran Lingkungan Fisik a. Suhu}

Musim hujan dan musim kemarau memiliki pengaruh pada tingkat suhu lingkungan. Pengaruh ini cenderung bersifat lokal dengan periode waktu tertentu. Hal ini dikarenakan tingkat suhu dan kelembaban lebih kompleks dan dipengaruhi oleh fenomena global, regional dan topografi serta vegetasi. Saat pergantian musim penghujan ke musim kemarau, kondisi suhu berkisar $23^{\circ} \mathrm{C}-31{ }^{\circ} \mathrm{C}$. Nyamuk Aedes aegypti bisa hidup pada suhu rendah tetapi metabolismenya menurun, bahkan terhenti bila suhu turun sampai dibawah suhu kritis, sebaliknya pada suhu lebih 
tinggi dari $35^{\circ} \mathrm{C}$ dapat mempengaruhi proses fsiologis, suhu maksimum untuk pertumbuhan nyamuk $25^{\circ} \mathrm{C}-30^{\circ} \mathrm{C}$ (WHO, 2005). Hasil dalam penelitian ini berbeda dengan penelitian Adrianto (2009), yang dilaksanakan pada bulan April 2009 dengan rancangan studi ekologi. Hasil uji statistik didapatkan tidak hubungan antara suhu dengan kejadian penyakit demam berdarah dengue $(\mathrm{p}=0,437)$ (Adrianto, 2009). Dalam penelitian ini tidak melakukan uji korelasi secara statistik. Oleh karena itu, tidak bias diketahui nilai

\section{b. Curah Hujan}

Kasus DBD merupakan salah satu penyakit yang setiap musim penghujan (menjelang, sedang dan setelah) menjadi faktor munculnya DBD akibat lingkungan yang mendukung perkembangan jentik Aedes aegypti sebagai penyebab DBD. Perubahan iklim menyebabkan perubahan curah hujan, suhu, kelembaban, arah udara sehingga berefek terhadap ekosistem daratan dan lautan serta berpengaruh terhadap kesehatan terutama terhadap perkembangbiakan vektor penyakit seperti nyamuk Aedes, malaria dan lainnyabaik menjelang musim maupun setelah musim hujan (Gubler, 2010).

Faktor curah hujan menjadi perhatian pada penelitian ini, dimana setiap musim hujan kejadian DBD akan menjadi permasalahan yang dihadapi masyarakat. Jika curah hujan tinggi dan akhirnya terjadi banjir, maka setiap selesai kejadian banjir diikuti dengan wabah DBD. Namun, jika curah hujan kecil dan dalam waktu yang lama akan menambah tempat perindukan nyamuk dan meningkatkan populasi nyamuk. Seperti penyakit berbasis vektor lainnya, DBD menunjukkan pola yang berkaitan dengan iklim terutama curah hujan karena mempengaruhi penyebaran vektor nyamuk dan kemungkinan menularkan virus dari satu manusia ke manusia lain (Yussanti, 2010). Curah hujan yang tinggi dan berlangsung dalam waktu yang lama dapat menyebabkan banjir sehingga dapat menghilangkan tempat perindukan nyamuk Aedes aegyptiyang biasanya hidup di air bersih. Akibatnya jumlah perindukan nyamuk akan berkurang sehingga populasi nyamuk akan berkurang (Dini, A.M.V, 2010).

Dari hasil uji regresi diperoleh nilai constant (nilai a) sebesar 16.727 dan nilai $b=0.131$, sehingga persamaan regresinya Kasus $\mathrm{DBD}=$ $16.727+0.131$ (curah hujan), dapat digunakan untuk memprediksi kejadian DBD, atau dengan kata lain, tidak ada korelasi antara curah hujan dengan kejadian DBD. Peningkatan curah hujan sebanding dengan peningkatan pertumbuhan jentik nyamuk DBD. Berdasarkan persamaan tersebut menunjukkan bahwa setiap peningkatan $1 \mathrm{~mm}$ curah hujan dapat memberikan perubahan peluang peningkatan kasus DBD sebesar 0.131 kasus. Hasil penelitian ini sejalan dengan penelitian lain, bahwa tidak ada korelasi antara faktor curah hujan dengan kejadian DBD, diduga karena faktor lain yang lebih besar peranannya. Adanya curah hujan yang tinggi, memungkinkan banyak bermunculan tempat perindukan nyamuk. Namun, curah hujan tersebut dapat menyapu tempat perindukan nyamuk tersebut secara alami maupun artificial (buatan). Kondisi hujan dan panas yang berseling pada pergantian musim lebih berpengaruh positif terhadap populasi nyamuk dikarenakan air hujan tidak mengalir dan menggenang di beberapa tempat. Peningkatan jumlah media perindukan nyamuk dan semakin menurunnya daya dukung lingkungan, diduga menjadi salah satu penyebab terjadinya hubungan yang tidak bermakna tersebut.

\section{c. Penggunaan Lahan}

Penggunaan lahan adalah usaha manusia memanfaatkan lingkungan alamnya untuk memenuhi kebutuhan tertentu dalam kehidupan dan keberhasilannya yang berdampak pada perubahan pemanfaatan lahan dari suatu fungsi ke fungsi lainnya untuk kegiatan tertentu (Thomas W. Hertel, Steven K. Rose, 2009). Di kabupaten $\mathrm{X}$ yang menjadi lokasi penelitian ini, penggunaan lahan terbesar pada tanah kering yang hingga saat ini telah digunakan untuk wilayah perumahan. Banyaknya perumahan yang saling berdekatan, semakin dekat pula jarak terbang nyamuk dalam proses penularan virus dengue. Ditambah lagi dengan kondisi perumahan yang bersih menjadi tempat favorit bagi perkembangan nyamuk Aedes Aegypti.

Dalam penelitian Tavares et al (2014), analisis spasial dan temporal mendalam dari perubahan penggunaan lahan di daerah pegunungan pedesaan untuk periode data 1965-2010. Ini menyangkut daerah pedesaan dengan karakteristik sebagian pegunungan dan prevalensi lahan hutan yang tinggi, mengkaji proses urbanisasi dan sistem pengelolaan lahan yang melibatkan negara dan masyarakat. Didukung oleh koleksi lima periode analisis citra (1965, 1974, 1983, 1995, dan 2010). Transisi spasial dan temporal menunjukkan 
peningkatan yang signifikan di daerah perkotaan, pengurangan daerah pertanian (Tavares, A.O., Mario Monteiro., M.A. Vargas., 2014). Hasil penelitian ini menyoroti pentingnya kebijakan publik dalam dinamika perubahan penggunaan lahan, baik dalam bentuk instrumen perencanaan atau peraturan terkait erat dengan masyarakat lokal dan berbasis pertanian dan sumber daya hutan.

\section{SIMPULAN}

1. Kejadian DBD dipengaruhi oleh faktor fisik yang meliputi suhu, curah hujan, dan penggunaan lahan.

2. Kejadian DBD tertinggi terjadi di Desa B dengan jumlah 80 kasus. Suhu rata-rata di Kabupaten $\mathrm{X} 27,70^{\circ} \mathrm{C}$, Curah hujan ratarata $236,75 \mathrm{~mm}$, dan penggunaan lahan sebesar untuk tanah sawah $509 \mathrm{Ha}$ dan penggunaan tanah kering 1.055,17 Ha.

3. Secara umum hasil penelitian ini tidak bisa menunjukkan nilai $p$ value karena penelitian ini bersifat deskriptif, tidak menguji korelasi. Jadi, bagi peneliti selanjutnya bisa melakukan penelitian dengan metode kuantitatif dan menguji korelasinya antar variabel serta mengembangkan sistem kewaspadaan dini dari hasil penelitian yang diperoleh.

\section{DAFTAR PUSTAKA}

Adrianto, M. (2009) Hubungan antara Unsur Iklim dengan Kejadian Penyakit DBD di Kota Semarang 1999-2008. Universitas Diponegoro.

Bouzid, M. et al. (2014) "Climate change and the emergence of vector-borne diseases in Europe: case study of dengue fever.," BMC public health, 14, hal. 781. doi: 10.1186/1471-2458-14-781.

BPS (2015) Karanganyar Dalam Angka Tahun 2014. Karanganyar.

BPS Kabupaten Karanganyar (2014) Geografis, Iklim dan Luas Wilayah. Karanganyar.

Brunkard, J. M. et al. (2007) "Dengue Fever Seroprevalence and Risk Factors, Texas
- Mexico," Emerging Infectious Diseases, 13(10), hal. 1477-1483.

Cahyati, W. H. (2006) "Dinamika Aedes Aegypti sebagai Vektor Penyakit Kesehatan Masyarakat,” 2, hal. 40-50.

Cheong, Y. L., Leitao, P. J. dan Lakes, T. (2014) "Assessment of Land Use Factors Associated With Dengue Cases in Malaysia Using Boosted Regression Trees.," Spatial and spatio-temporal epidemiology. Elsevier Ltd, 10, hal. 7584. doi: 10.1016/j.sste.2014.05.002.

Dini, A.M.V, R. N. F. dan R. A. W. (2010) "Faktor Iklim dan Angka Insiden Demam Berdarah Dengue di Kabupaten Serang," Jurnal Kesehatan, 14(1).

Gubler (2010) The Global Threat of Emergent/re-emergen Vector-borne Diseases. In : Atkinson. Vector Bio. New York: Springer.

Majidah, A. (2009) Hubungan Faktor Iklim dan Angka Insiden Demam Berdarah Dengue di Kabupaten Serang Tahun 2007-2008. Universitas Indonesia.

Sari, L. (2011) Hubungan Faktor-Faktor Iklim dengan Kejadian Penyakit DBD di Kabupaten Cilacap Tahun 1998-2010. Universitas Diponegoro.

Sitorus, J. (2003) Hubungan Iklim dengan Kasus Penyakit Demam Berdarah Dengue (DBD) di Kotamadya Jakarta Timur. Universitas Indonesia.

Tavares, A.O., Mario Monteiro., M.A. Vargas., R. S. (2014) "Land Use Change and Forest Routing in a Rural Context: The Relevance of The Community-Based Management and Planning Framework," Applied Geography, 52, hal. 153-171. doi: 10.1016/j.apgeog.2014.05.008.

Thomas W. Hertel, Steven K. Rose, R. S. J. T. (2009) Economic Analysis of Land Use in Global Climate Change Policy. I. New York: Routledge Inc.

WHO (2005) Panduan Lengkap Pencegahan dan Pengendalian Demam Berdarah 
Jurnal Manajemen Informasi dan Administrasi Kesehatan (J-MIAK)

Volume 01, No 01, Tahun 2018

ISSN: 2621-6612

Email: d3perinfokesunivet@gmail.com

Halaman: 22-28

Dengue. 1th Editio. Diedit oleh P. Widyastuti. Jakarta: Buku Kedokteran EGC.

Yussanti, N. (2010) Pemodelan Wabah DBD di Jawa Timur Berdasarkan Faktor Iklim dan Sosio Ekonomi dengan Pendekatan Regresi Panel Semi Parametrik. Institut Teknologi Surabaya. 